British Journal of Education

Vol.8, Issue 3, pp.134-147, March 2020

Published by ECRTD- UK

Print ISSN: ISSN 2054-6351

Online ISSN: ISSN 2054-636X

\title{
AVAILABILITY OF EDUCATIONAL RESOURCES FOR QUALITY ASSURANCE IN SECONDARY SCHOOLS
}

\author{
Ugochukwu K. Agi (Ph.D.) \\ \& \\ Tessy Lucky Uba
}

Department of Educational Management, Faculty of Education, Ignatius Ajuru University of Education, P.M.B. 5047, PHC, Rivers State, Nigeria.

\begin{abstract}
This work looked at the availability of educational resources for quality assurance in secondary schools. Educational resource is seen as the physical, material, human and financial inputs in the teaching-learning process. Quality is viewed as an accepted standard measure by which product are judge as fine enough for consumption. Quality assurance is termed as the processes and actions through which the quality of secondary education is maintained and developed. The work also examined the need for quality assurance in secondary schools, strategies for establishing quality assurance in education, quality assurance measures put in place to guarantee finesse of product, availability of facilities, instructional materials, human resources and financial resources that brings about quality assurance in secondary schools. The work revealed that physical facilities, teaching and non-teaching staff as well as instructional materials were highly insufficient. The study further revealed that annual subvention to schools was less than the amount required for the administration of the schools. Based on these findings, the work concluded that quality assurance in secondary schools is crippled by insufficient educational resources. Therefore, the work suggested among others that; government should increase the annual subventions to schools, parent teachers' association and old students' association should also be involved in the funding and maintenance of the school facilities, the ministry of education should have a unit whose duty is to monitor the funds available to avoid misappropriation.
\end{abstract}

KEYWORDS: educational resources, quality, assurance, quality assurance, insufficient, annual subvention, secondary school and educational system.

\section{INTRODUCTION}

The word education is solely utilized for the advancement of people in the subjective, emotional, psychomotor and psycho-productive fields. It is widely accepted as a major instrument for promoting socio-economic, political and cultural development of any nation. Education also helps to determine the economic wellbeing of an individual as well as that of the society. Secondary education is the bridge between primary and tertiary levels of education. It is the education that children receive after the primary education and before the tertiary stage.

N.P.E (2004) established that secondary education is expected to: 
British Journal of Education

Vol.8, Issue 3, pp.134-147, March 2020

Published by ECRTD- UK

Print ISSN: ISSN 2054-6351

Online ISSN: ISSN 2054-636X

a. Provide all basic school leavers with the open door for education at a more significant level independent of sex, societal position, religious or ethnic foundation.

b. Offer expanded educational program to cater for the distinctions in skills, openings and to future jobs.

c. Provide skilled labour in applied science, innovation and business at sub-proficient evaluations.

d. Develop and advance Nigeria dialects, art and culture with regards to world cultural legacy.

e. Inspire its understudies with want for personal development and accomplishment of greatness.

f. Foster national solidarity with an accentuation on the regular ties that joins us in our assorted variety.

g. Raise an age of individuals who can have an independent mind, regard the sentiment of others, regard the pride of work, welcome those qualities determined under our expensive national objectives and live as productive members of society.

h. Provide specialized information and professional abilities important for farming, modern, business and financial improvement.

This means that the quality of teaching and the facilities in our institutions especially in secondary schools should be geared towards achieving the above objectives. The underlying principle here is that the secondary schools should be able to provide quality education to all those who can benefit from it, as the worth of any educational system lies in its capability to continuously serve its society better and remain relevant. However, the educational systems in developing countries are not able to fulfil these responsibilities as a result of long-standing problems of finance, efficiency, equity, quality and governance (Hoop, 2010).

The primary aim of every organization is to accomplish predetermined goals and objectives which cannot be realized in a vacuum. One of the fundamental conditions for effective realization of organizational goals is the adequate provisions of educational resources. However, Nigeria as a nation has made giant strides in expanding her educational system. With the rapid increase in the number of schools at almost every level of the educational systems and giving the limited financial, human, material and physical resources, the concern of parents, government, teachers has been with the quality of education being offered in these institutions. Babalola (2008) stated that quality education is measured by the extent to which the training received from an institution enables the recipient to think clearly, independently and analytically to solve relevant societal problems in any given environment. A quality education in this submission expects an educational system which a person has passed through to affect the attitude, aspiration and action of such beneficiary. Nwana (2000) declared that quality in education alludes to the size of resources in form of assets, equipment, offices, educators and students and the yields of the institutions in terms of their items that are worthy, alluring and productive from the point of view of the stakeholders. This means that there must be acceptable standards of excellence in the total environment of a school system. While quality assurance in the school system is all activities that are conducted in order to achieve or maintain a certain quality level in every participant. It is an avoidance of defect in educational 
British Journal of Education

Vol.8, Issue 3, pp.134-147, March 2020

Published by ECRTD- UK

Print ISSN: ISSN 2054-6351

Online ISSN: ISSN 2054-636X

process. Cole (2011) viewed quality assurance in any educational institution as a concept that indicates that students' learning is well supported with adequate resources among which are funding, physical facilities, human resources, maintenance of facilities and instructional materials. Classroom form a major part of the physical facilities of a school environment which is one of the predictors of quality assurance. It is a very important part of a school plant, as no meaningful learning can take place where classrooms are inadequate. It is the hub of every learning interaction between the teacher and students. Nwagwu (2003) stated that the number of classrooms required in a school should reflect the population of the student and staff for quality to be ensured. UNESCO (2004) recommended that secondary school class size should not exceed 35 pupils. Aleude, Okhiku, Esamah and Ojiemenkele (2010) reported that classrooms in most secondary schools have become human poultry as more than 50 students are made to learn in a classroom which is at variance from the expected. They also affirmed that classrooms in some secondary schools are substandard as they are not large enough to accommodate the number of students.

The importance of infrastructure for quality assurance in secondary schools cannot be overemphasized. However, many secondary schools in Nigeria lack adequate essential infrastructure to enable them function as safe, efficient and effective schools. Realizing this ugly trend, F.M.E (2009), decried the deplorable state of the public secondary schools. They stated that facilities in schools were in poor conditions and that the existing ones have outlived their usefulness. They lamented that this was going to affect the academic achievement of the students who are made to learn under such conditions as they lack the desired comforts that will make them learn. This poor state of infrastructure is found in both urban and rural schools. The physical state of classrooms is very poor with floors full of holes, roofs and broken ceilings. In some instances, furniture is stolen, and classrooms used as toilet. This can adversely affect quality assurance in schools.

Oladipo (2009) also reported that teaching facilities including audio-visual materials are not only inadequate but absent in many secondary schools. There are no laboratories at all in most schools where there are introductory technology workshops, all the nuts of the machines are missing, and the workshops are long-abandoned as there are no trained teachers to operate the equipment. $\mathrm{He}$ also reported that libraries are not available in many schools and where they are, books are inadequate or obsolete. To ensure quality in educational system, schools also require adequate quality teachers in order to meet the needs of the school. The inadequacy of human resource who are to bring about quality assurance in our secondary schools, gives cause to worry because it is at this stage that career decisions are made. The system will succeed if the human resource inputs, such as teaching and non-teaching staff are adequate. They are to be mobilized and deployed by the school to attain its goals, they are the most significant because they utilize all other resources to make them productive. Money and materials will be useless if there are no persons to make them work for the school. Saliu (2003) concluded that inadequate staff in secondary schools is one of the problems confronting the educational development. He declared that the number of teachers of the primary and secondary school level is grossly inadequate. 
British Journal of Education

Vol.8, Issue 3, pp.134-147, March 2020

Published by ECRTD- UK

Print ISSN: ISSN 2054-6351

Online ISSN: ISSN 2054-636X

Another predictor of quality assurance in secondary schools is adequate funding. Nigeria secondary schools have over the years suffered inadequate funding. Kayode (2002) expressed that absence of satisfactory subsidizing has obviously impeded the exhibition and standard of secondary education as the endless loop of lacking assets, weakness, disappointment is persistently felt in a commonly fortifying way. Nwangwu (2003) attributed inadequate provisions of funds mainly to the lack of political will and determination of priorities by government, rather than shortage of national funds.

In recent times, government and non-governmental organizations have made efforts to provide facilities to some schools. One of these is the renovation of some schools and provision of desk/benches to some selected schools in various states by the state governments. Though the government and non-governmental organizations have made some efforts, there seems to be a consistent problem of inadequacy of educational resources in some secondary schools. This seems to suggest that the efforts have not yielded an appreciable impact.

\section{Concept of Educational Resources}

Educational resources can be categorized into four groups that is; human, material, physical and financial resources in the teaching learning process (Adeogun \& ofisila, 2008). They are integral to the instructive procedure since they assume a significant role in the accomplishment of instructive objectives and targets since they encourage educators' work and quicken learning with respect to the understudy (Usman, 2007). Hallak (2007) emphasized that the availability of relevant educational resources contributes to quality assurance and that unattractive school buildings, crowded classrooms, non-availability of playing grounds and surroundings that have no aesthetic beauty can contribute to poor quality in education. Babalola (2008) posited that private schools perform better than public schools because of availability and adequacy of teaching and learning resources. Hoop (2010) noted that education in most sub-Saharan countries faces chronic shortages in physical and human resources. According to him, rather than distributing the limited resources available for secondary education uniformly across schools, many governments allocate a relatively large share of available resources to a selected number of secondary schools. Similarly, findings by World Bank (2008) in a study on provision of textbooks and physical resources in secondary schools in sub-Saharan African countries: Botswana, Cameroon, Coted'vore, Ghana, Kenya, Malawi, Rwanda, Tanzania and Togo revealed that urban secondary schools have better textbook supplies and physical facilities than those in the rural areas. An earlier study by Fabunmi in Okosun (2015) on differential allocation of educational resources and secondary school quality assurance in Edo state in Nigeria noted that there was a common feature of difference in allocation of facilities to schools.

\section{Concept of Quality Assurance in Education}

Quality has been seen differently by various scholars and it has been at the top burner in the present day national and international perspectives. Quality is viewed in terms of the ability of the students to go beyond passing summative exams or test to passing formative and other standard exams. It 
British Journal of Education

Vol.8, Issue 3, pp.134-147, March 2020

Published by ECRTD- UK

Print ISSN: ISSN 2054-6351

Online ISSN: ISSN 2054-636X

is also having the knowledge through an educational process which is relevant to solving problems in the society and useful to the immediate environment.

Merriam-Webster's collegiate dictionary (2003) viewed quality as the degree of worth of goodness that distinguishes one thing from another. Green and Harvey (2000) posited quality to mean the following:

- Something that is consistent (exhibited zero defeat and getting right the first time, making quality a culture).

- Something that has fitness for purpose (meaning the product or service meeting the stated purpose, customer specifications and satisfaction).

- Something that has value for money (through efficiency and effectiveness) and

- Something that is transformative in terms of quality change. The feature in the meeting of organizational goals.

- Relevance to human and environmental needs and

- Pursuit of excellence.

Jaiyeoba and Atanda (2005) opined that quality is synonymous with standard, proficiency, greatness, importance, and value. At the point when applied to education, it is the accomplishment with which an institution gives instructive condition which empowers understudies to viably accomplish beneficial learning objectives including suitable scholarly standard. The educational work delivery by the school personnel must transcend from just performance of specific duty to the achievement of goals in a way that would meet stated or implied need of the educational system at all levels. Khedkar and Pushpanadham (2015) termed quality to be a philosophy that aligns the activities of all the stakeholders in the education system with the common focus of customer satisfaction through continuous improvement of the educational system. Assurance on the other hand is seen by Merriam-Webster's collegiate dictionary (2003) as a state of having confidence in oneself or having belief and trust in one's own power. Guaranteeing the arrangement of value education is a major part of picking up and keeping up validity for projects, establishments and national arrangement of advanced education around the world. Quality assurance is designed to improve the quality of an institution's methods and educational products and outcomes (Ajadi \& Awe, 2011). Harvey (2000) opined that quality assurance is the way toward guaranteeing powerful asset inputs, control, refining the procedure and increasing the expectations of yield to meet the set objectives and fulfill open responsibility. This definition brings out the issue of promoting good value in the institutional management of teaching-learning process to produce quality learners from school system. Campbell and Rozenyai (2002) on their part posited that quality assurance is a term that covers policies, processes and actions through which the quality of secondary education is maintained and developed. It is a procedure through which secondary education institution promises itself and its partners that its teaching-learning and different administrations reliably arrive at a standard of greatness. Quality assurance is a comprehensive term that applies to the planned systematic actions necessary to provide adequate confidence that a product or service will satisfy a given requirements for quality (Khedkar \& Pushpanadham, 2015). In addition, Ajayi and Adegbesan (2010) argued that quality assurance also covers the entire process of accountability in 
British Journal of Education

Vol.8, Issue 3, pp.134-147, March 2020

Published by ECRTD- UK

Print ISSN: ISSN 2054-6351

Online ISSN: ISSN 2054-636X

the maximization of the effectiveness and efficiency of the educational system and services as it pertains to their contexts, mission and stated objectives. Hence, quality is not diversely pursued, rather, the rating scale of quality is based on the predetermined objective and the institutional context of the process that assures quality. Quality must meet the mission statement and the broader vision of the organization. Nwagwu (2003) distinguishes the following areas of reform that will improve the outcomes and results for quality assurance at secondary school level thus: quality of primary school leavers; class size and student-teacher ratio; secondary school curriculum; teaching and learning facilities and materials; teacher quality and morale; time utilization and management, discipline and character formation and funding arrangement, among others.

\section{The Need for Quality Assurance in Secondary Schools}

The need for quality assurance in secondary schools must be stressed to ensure the quality of teaching and learning. Adegbesan (2010) emphasized the following as some of the major needs for quality assurance in Nigeria secondary school system.

- To serve as indispensable component of quality control strategy in education.

- To guarantee and keep up exclusive expectation of education at all levels.

- $\quad$ To help with observing and supervision of instruction.

- To decide the quantity of classrooms required based on the normal class size to guarantee quality instruction.

- $\quad$ To decide the degree of sufficiency of the offices accessible to quality control.

- It would guarantee how the money related assets available could be wisely and reasonably used.

\section{Strategies for Establishing Quality Assurance in Education}

Adegbesan (2010) identified the strategies used for quality assurance in education as follows:

a. Evaluation: This is a formal process that is carried out within the school setting. Evaluation is based on the availability of data which can be used to draw conclusions. The main purpose of evaluation as a strategy that will bring about quality assurance is to see how the school system can be aided to advance on the current level of performance.

b. Supervision: This is a friendly guidance and direction given to teachers and pupils to enable them to improve on themselves and the teaching-learning process that will help to accomplish the desired goals of education. It is an attempt at bringing about improvement in education.

c. Inspection: Inspection is more of an assessment of available facilities and resources in an institution. It helps to establish how far a certain organization has met a given standards. The main aim of inspection is to ensure that the school system uphold a high standard.

d. Monitoring: Monitoring is a procedure that helps to oversee ongoing projects or programmes within the school system. Data are usually collected at intervals to achieve this aim. This helps to constantly assess the level of performance.

e. Quality control: This strategy for establishing quality assurance in the educational system at all levels helps to scrutinize the qualification of teachers, the suitability of the 
British Journal of Education

Vol.8, Issue 3, pp.134-147, March 2020

Published by ECRTD- UK

Print ISSN: ISSN 2054-6351

Online ISSN: ISSN 2054-636X

curriculum, availability of the required number of equipment and the proper use of the processes involved in the skills that will bring about high standard in the school system.

Igborgbor (2012) asserted that all the strategies delineated above have been carried out at the various levels of education in Nigeria by diverse bodies designated for this purpose. He reported that about five decades ago, inspectors usually turned up unannounced at the mission schools. They monitored the school's activities and generally kept the teachers on their toes. During the first three decades of independence, the inspectorate division was well established at both the federal and regional/state levels. Inspection of schools was a routine task of these divisions for school administrators. The only hurdle according to him was that the evaluation results were more of summative (cumulative assessment) than formative (influence development). There was no active feedback mechanism for utilizing the result for improvement of practice in the schools. As a result of rapid expansion of access to education from the universal primary education (UPE) and the declining allocation of funds to the sector, the inspectorate function of the ministry of education had died an unnatural death.

\section{Quality Assurance Agencies in Nigeria}

Okon and Akpan (2011) listed the following as quality assurance agencies in Nigeria

1. West Africa Examination Council (WAEC)

2. National Examination Council (NECO)

3. National Board for Technical Education Commission (NABTEC)

4. National Commission for College of Education (NCCE)

5. National Board for Technical Education (NBTE)

6. National University Commission (NUC)

7. Quality Assurance and Research Development Agency (QAARDAN)

These bodies ensure quality of programmes through routine inspections, policy formulations and implementation, provision of infrastructure, accreditation and certification, among others. Ekwere (2012) stated that these bodies constitute external quality assurance mechanism. The internal quality assurance mechanism comprises of managerial and academic quality control monitoring groups. These bodies and groups work relentlessly to attain significant level of quality assurance in Nigeria education system.

\section{Availability of Facilities for Quality Assurance}

Facilities are plants, equipment, building, furniture; such as tables and chairs which enables workers to perform their work effectively. Jaiyeoba and Atanda (2005) posited that educational facilities are those things which enable a skillful teacher to achieve a level of instructional effectiveness that far exceed what is possible when they are not provided. UNESCO (2004) classified educational facilities as hardware (apparatus or equipment used for educational resources) on the one hand, and the software (programmes, books and other materials) on the other hand used in the teaching and learning process. From this point of view, educational facilities are important in the development of the three domains of knowledge, utilities and skills that resides in 
British Journal of Education

Vol.8, Issue 3, pp.134-147, March 2020

Published by ECRTD- UK

Print ISSN: ISSN 2054-6351

Online ISSN: ISSN 2054-636X

every man. Effectiveness in the use of materials is directed largely by the operational use of facilities. Despite the relevance of educational facilities to the attainment of quality assurance in secondary school education, problems still exist. The issue at stake is whether these facilities being provided are effective in the implementation of secondary education curriculum for the achievement of quality education?

Oladipo (2009) who investigated on the state of facilities in schools reported that students learn in deplorable and inadequate classrooms which is a major problem in Nigeria schools. According to him, a visit to schools shows that some students sit on the bare floor during lessons, some will have to stand or squat as a result of congestion in the classrooms which hinders proper learning from taking place. For the students, it is all about acquiring certificate and not the development of their intellects. UNESCO (2004) affirmed that without adequate physical facilities, no worthwhile learning can take place. With the tremendous increase in enrolment, one should have expected government authorities to match large numbers of students with appropriate and adequate facilities. Since it appears that the problem of mass enrolment has come to stay, there is urgent need for something to be done about provision of physical facilities so that quality will not be compromised.

\section{Availability of Instructional Materials for Quality Assurance}

Instructional material is anything that enhances the process of teaching and learning. Instructional materials aid the process of teaching in the sense that using them enables the learner to grasp what the teacher is trying to put across to them more easily and more perceptually (N.T.I, 2000). They also see instructional materials as anything in form of instruments or equipment that can be used to assist teaching and learning in and outside the classroom. Dehar and Faize (2011) explained that instructional materials are print and non-print items that are designed to impart information to students in the educational process. According to them instructional materials include items such as kits, textbooks, magazines, newspapers, pictures, recordings, slides, transparencies, video discs, workbooks and electronic media including music, movies, radio software, CD ROMS, and on-line services. They also see instructional materials as school resource inputs that is used within the classroom to facilitate the teaching learning process.

Ajayi (2009) enumerated types of instructional materials at the disposal of the teachers as visual, audio visual aids. Visual materials are objects learners can see, like real objects, models, pictures and graphs, while audio according to them are materials that the learners could hear, like radio, cassettes, recorded sounds. Audio visual are the instructional materials that appeal to both sense of seeing and hearing. A typical audio-visual instrument is the television. This is very effective because what is heard is further reinforced by the visual image. Ajayi in his work on obstacles to efficiency of education in Nigeria identified the importance and state of instructional materials in secondary schools. He stated that for learning to take place, there is the need for the teacher to sensitize pupils' sense of seeing, hearing, smelling and touching using instructional materials. He however discovered that the instructional materials required for effective teaching and learning in Nigerian schools are grossly inadequate. He stressed that it is a common knowledge that 
British Journal of Education

Vol.8, Issue 3, pp.134-147, March 2020

Published by ECRTD- UK

Print ISSN: ISSN 2054-6351

Online ISSN: ISSN 2054-636X

instructional materials such as radio, television sets and computers are rarely available in most schools. Where instructional materials are inadequate, teachers will be less efficient in instructional delivery and this will affect the quality of outputs from the school system. There is therefore the need to ensure adequate supply of instructional materials to schools. Arogundade (2009) explained that teaching without instructional materials is like tea without sugar. He posited that effective teaching and learning process cannot be guaranteed where there are no instructional materials to use. He emphasized that schools should provide instructional materials for the teachers so that they can do their job effectively. In the alternative according to him, teachers should improvise instructional materials to complement the school efforts in this regard. He further stated that instructional materials like audio or visual will make the teaching-learning process lively for pupils and that students will derive pleasure in attending school regularly when they know that new materials are going to be employed by teachers in teaching them different subjects.

\section{Availability of Human Resources for Quality Assurance}

The importance of human resources in any organization can never be overstretched as they are the personnel that make up the workforce of any organization and they contribute significantly to its success. Ajayi (2009) noted that for a school system to achieve the objectives for which it is established, the functionaries, particularly the principal, the teaching staff and the non-teaching staff need to work together as a team, as nobody has solutions to all problems. No matter the skill, knowledge and competence of any individual, he or she still needs the assistance and support of others to succeed. According to him, the ability to work with others and benefit from their ideas, knowledge and views will go a long way to ensure quality in the system. He further stressed that the social cohesiveness, unity and team maintenance in an organization has become part of the functions of contemporary managers who want to succeed. Olubawo (2008) likewise stated that no education can rise above the quality of the teacher. According to her, teachers are the most important of all the inputs that go into educational provision. This is because education of the highest quality requires efficient teaching. She posited that education in Nigeria lack quality teachers, and this has contributed to the decline in the quality of education.

Fagbamiye (2005) affirmed that the quality of a teacher that is measured by experience and qualification is more predictive of students' performance and achievement and that since the quality of teachers determine the quality of teaching, and teaching is the bedrock of knowledge, adequate qualified teachers is imminent. He said that there has been a noticeable decline in the quality of teaching from the early 90s unlike the impressive rise that began from 1948 to the close of the oil boom era around 1985. Between 1948 and 1973, great scholars and teachers from top overseas institutions were part of the teaching pool in our secondary schools. The welfare packages for teachers were attractive and facilities such as books, and well well-equipped laboratories were available to support instructional process. All these combined to enhance sound and quality teaching. There was however change in the system from 1973 and it became worst by the economic recession witnessed seven years later when it became difficult to maintain the existing facilities let alone purchasing and installing new ones. 
British Journal of Education

Vol.8, Issue 3, pp.134-147, March 2020

Published by ECRTD- UK

Print ISSN: ISSN 2054-6351

Online ISSN: ISSN 2054-636X

Onyeachu (2012) also attributed the low level of quality assurance to inadequate staffing. He lamented that in most secondary schools, the few teachers available are given heavy workload to the extent that in most cases, teachers are compelled to teach subjects that are not their areas of specialization. A teacher who read Christian religious knowledge is made to teach Biology and Physics, one wonders the type of knowledge he is going to impart to the learners since no teacher teaches what he does not know. Teachers workload include time spent on teaching, preparation of lessons, organizing and preparation of teaching aids, giving and marking assignments, mastering the subject content, the number of classes and the number of students taught in the class. Some teachers may be asked to work outside their jurisdiction. The effect of all these is that teachers may not be able to maximize their input for effective learning and the quality of education is directly related to the quality of teaching in classrooms.

\section{Availability of Financial Resources for Quality Assurance}

Financial resource is one of the inputs essential for quality assurance in Nigerian secondary school education. This is because it provides the necessary purchasing power with which education acquires its human and material inputs. If the educational system is adequately funded, then quality in education can be ensured. To enhance the teaching and learning process, such funds will be used to improve the necessary school facilities. Okunola (2005) talked on the importance of finance in the management of school. He said that financial costs are expressed as capital and recurrent cost. Expenditure incurred on the construction of new schools, libraries, laboratories and provision of furniture items are under capital cost while payment of salaries, provision of textbooks, stationaries, maintenance of building facilities and equipment are recurrent cost. Therefore, in discussing materials/equipment, finance will not be left out. For without finance, the materials will not be purchased. Mohammed (2008) affirmed that the total fund required to meet the needs of the schools to say the least is huge. He opined that running an educational system requires significant investment in providing and maintaining a basic level of infrastructure such as facilities, staff salaries, and instructional materials but lamented that education has been grossly under-funded which has affected the quality of education in Nigeria.

Kayode (2002) in his studies identified lack of adequate funding as one of the factors hampering secondary education in Nigeria. Akindutire and Ajayi (2007), and Adegbite (2007) in similar studies reported that inadequate funding is the major challenge facing management of secondary school education in Nigeria. They argued that there was an increase in the proportion of total expenditure devoted to education, but this has been rather grossly inadequate considering the remarkable increase in student enrolment and cost which has been heightened by inflation. Ajayi (2009) expressed that the Nigeria government throughout the years have not been meeting the 2004 United Nations Educational and Cultural Organization (UNESCO) recommendation of 26\% of the complete spending portion to education sector. Aina (2007) revealed that government priority to education is still very low. These disclosures depict the degree to which the government itself is a causative influence on the financial problems of the system. Adedeji (2008) likewise opined that education is poorly funded in all African countries and that the people are clamoring for proper funding of secondary education. They believe that funding of secondary education is 
British Journal of Education

Vol.8, Issue 3, pp.134-147, March 2020

Published by ECRTD- UK

Print ISSN: ISSN 2054-6351

Online ISSN: ISSN 2054-636X

the only instrument that can bring about dramatic change in Africa secondary education system. According to him, this issue is very sensitive one as it is through proper funding that secondary schools can have the opportunity of competing with their counterpart in other parts of the world.

\section{CONCLUSION}

This work assessed the availability of educational resources for quality assurance in secondary schools. Quality assurance is designed to improve the quality of education and to raise the standards of output in order to meet set goals and objectives of the educational system. Based on the findings, educational resources in secondary schools that will ensure quality assurance is highly inadequate. If the goals and objectives of education must be met, then urgent steps need to be taken to proffer lasting solution to the problems of inadequate educational resources if not the much talked about quality assurance in secondary schools will continue to be a ridiculous expectation or wish that can never be accomplished.

\section{SUGGESTIONS/RECOMMENDATIONS}

It should be clearly noted that educational resources like finance, human resources, instructional resources and facilities are strong determinants for quality assurance in secondary schools. It is on this bases that the following suggestions/recommendations are made:

1. The government as a matter of urgency should increase the annual subventions to schools so that the issue of inadequate educational resources can be nipped in the bud.

2. The ministry of education should ensure that there is benchmark for facilities in schools and policy statement on benchmark regarding funding so that what is sent to schools can be compared with the benchmark to determine the level of funding.

3. Parent teachers' association in collaboration with old students' association should also be involved in the funding and maintenance of the school facilities.

4. The ministry of education should have a unit whose duty will be to monitor the state of affair of the schools because it is possible for fund to be made available, but it will be misappropriated.

5. Subject areas where teachers are inadequate should be addressed by the ministry of education.

\section{References}

Adedeji, T. (2008). Reformation, revitalization and re-orientation in higher education. Which way Africa? A policy recommendation towards quality in African higher education. Ibadan: HERPNET Publishers.

Adegbesan, S.O. (2010). Establishing quality assurance in Nigeria education system. Implication for educational managers. Ado-Ekiti: PETOA Educational Publishers.

Adegbite, J.G.O. (2007). Administering and managing universities. Ibadan: Mosauro Publishers. 
British Journal of Education

Vol.8, Issue 3, pp.134-147, March 2020

Published by ECRTD- UK

Print ISSN: ISSN 2054-6351

Online ISSN: ISSN 2054-636X

Adeogun, A.A., \& Osifila, G. (2008). Relationship between educational resources and student's academic performance in Lagos State Nigeria. International Journal of Educational Management 5(6), 36-39.

Aina, O.L. (2007). Alternative modes of financing higher education in Nigeria and implication for university governance. Lagos: Balabay Publishers.

Ajadi, T.O., \& Awe, B. (2011). Issues and challenges of quality assurance in open and distance learning institutions in Nigeria. A publication of the department of educational management university of Ibadan. African Journal of Educational Management 14(2), 63-69.

Ajayi, I. A. (2009). Funding initiatives in university education in Nigeria. A paper introduced at the national conference of the national association for education administration and planning. Enugu state university of science and technology.

Akindutire, I.O., \& Ajayi, I.A. (2007). The unresolved issues of quality assurance in Nigeria universities. Journal of Sociology and Education in Africa 6(3), 51-57.

Aleude, R., Okhiku, I., Esamah, I., \& Ojiemhenkele, A. (2010). An appraisal of the policy on education. Journal of Studies in Education 8(1), 70-80.

Arogundade, B.B. (2009). Classroom management in education. Theories and tasks. Lagos: Macmillan Publishers Limited.

Babalola, J.B. (2003). Budget preparation and expenditure control in education. Ibadan: Awe mark Industrial Printers.

Campbell, C., \& Rozenyai, C. (2002). Quality assurance and the development of course programmes. Papers on higher education regional university network on government and management of higher education in South Europe. Bucharest: Albatross Media.

Cole, G.A. (2011). Management theory and practice. London: South West Centage Learning.

Dehar, M.A., \& Faize, F.A. (2011). Effect of the availability and the use of instructional materials on academic performance of students in Punjab (Pakistan). Middle eastern finance and economics. Euro Journals Publishing 11(1), 87-94.

Ekwere, A.U. (2012). Curriculum evaluation and quality assurance in undergraduate business education programme in tertiary institutions in Nigeria. A Journal of Research in Education 18(1), 72-75.

Fagbamiye, E.P. (2005). Inequalities in Nigeria education. Towards genuine revolution in education. Lagos: University of Lagos press.

F. M. E. (2009). Federal Ministry of Education (Nigeria). Roadmap for the Nigerian education. Block 5A ( $8^{\text {th }}$ floor) Federal Secretariat Complex, Shehu Shagari Area, P.M.B. 146, Garki, Abuja.

Green, D., \& Harvey, M.N. (2000). An assessment of past and current approaches to quality in higher education. Australian Journal of Education 43(3), 107-112.

Hallak, J. (2007). Corrupt schools, corrupt universities: What can be done. Paris: UNESCOLLEP.

Hoop, J. (2010). Selective secondary education and school participation in Sub-Saharan Africa. Evidence from Malawi. Amsterdam: Tinbergen Institute. 
British Journal of Education

Vol.8, Issue 3, pp.134-147, March 2020

Published by ECRTD- UK

Print ISSN: ISSN 2054-6351

Online ISSN: ISSN 2054-636X

Igborgbor, G.C. (2012). Quality assurance for educational development in Africa. A Research Journal of the Institute of Education, Delta State University, Abraka 18(1), 45-50.

Jaiyeoba, A.O., \& Atanda, O.I. (2005). Quality assurance in Nigeria education system: Challenges to government in G.O. Akpa, S.U. Udoh \& E.O. Fagbamiye (Eds), Deregulating the provision and management of education in Nigeria (98-103). Jos: M.P Ginac Concept Ltd.

Kayode, M.O. (2002). Managing change in a Nigerian university setting. Ibadan: University Press.

Khedkar, P.D., \& Pushpanadham, K. (2015). Quality assurance system in secondary schools: School inspection. Beau Bassin: LAP LAMBERT Academic Publishing.

Merriam-Webster's collegiate dictionary (2003). (11 ${ }^{\text {th }}$ Ed.). Springfield, Massachusetts: Merriam Webster Incorporated.

Mohammed, A.M. (2008). Strategies and resources in the implementation of universal basic education $(U B E)$ programme. A lead paper presented at the $10^{\text {th }}$ faculty of education conference, Lagos state university, held on $31^{\text {st }}$ July 2008.

N.P.E (2004). National Policy on Education. Federal Republic of Nigeria. Fourth edition. Abuja: NDERC.

National Teachers Institute (2000). Evaluating and developing teacher's material. Module 13, unit 9. Kaduna: NTI Publishers.

Nwana, O.C. (2000). Introduction to educational research. Ibadan: Heinemann Education Books Ltd.

Nwagwu, N.A. (2003). The organization and management of primary and secondary education in Nigeria. Keynote address presented at the NAEAP 2003 annual conference at the university of Ibadan. October $28^{\text {th }}-31^{\text {st }}$.

Okon, E.E., \& Akpan, V.C.J. (2011). Access, product and quality assurance in technical vocational education. International Journal of Educational Development 13(11), 35-48.

Okosun, M. (2015). Assessing the adequacy of educational resources for quality assurance in secondary schools in Delta and Edo States. An unpublished Ph.D. thesis, department of educational administration and policy studies, Delta State University, Abraka.

Okunola, A.A. (2005). Resource utilization and projection in secondary schools in Oyo state of Nigeria. Unpublished Ph.D. thesis, university of Ibadan.

Oladipo, S.A. (2009). Management of primary and secondary education. A new approach. Warri: Jonakase Nigeria Ltd.

Olubawo, B.V. (2008). Delimiting factors to instructional media utilization in Nigeria school. Journal of curriculum and instruction 8(1), 196-206.

Onyeachu, J.A.E. (2012). The effect of learning environment and facilities on pupil's performance. A Journal of Basic Education in Nigeria 2(2), 11-20.

Saliu, M. (2003). Quality assurance in teacher education. A paper presented at the National Teacher Institute (NTI's) $25^{\text {th }}$ Anniversary Celebration, Kaduna.

UNESCO (2004). United Nations Educational Scientific and Cultural Organization. Reducing wastage and increasing efficiency in education: Final report of meeting of higher 
British Journal of Education

Vol.8, Issue 3, pp.134-147, March 2020

Published by ECRTD- UK

Print ISSN: ISSN 2054-6351

Online ISSN: ISSN 2054-636X

education partners (World Conference on Higher Education) Paris. UNESCO, 23-28 June.

Usman, A. (2007). The relevant material resources to the teaching and learning of Arabic and Islamic studies. An Encyclopedia of the Arts 7(1), 47-52.

World Bank (2008). Education for all. Fast track initiative, fact sheet.

http://www.education.fast-track.org 